\title{
車椅子 8 の字駆動テストの開発へ向けた予備的検討 Development of the Figure-of-8 Wheelchair Propulsion Ability Test: a Pilot Study
}

\author{
亀ヶ谷忠彦1)，藤田 貴昭 ${ }^{2}$, 相馬 正之 ${ }^{3)}$
}

Tadahiko Kamegaya, OTR, $\mathrm{PhD}^{1)}$, Takaaki Fujita, OTR, $\mathrm{PhD}^{2)}$, Masayuki Soma, $\mathrm{RPT}, \mathrm{PhD}^{3)}$

\begin{abstract}
要旨：[目的]車椅子の方向転換や加速・減速といった駆動のスキルの評価に用いる測定・
評価法の絶対信頼性および相対信頼性を，健常成人を対象として検証すること。

[方法］検者は作業療法士 2 名，被検者は健常成人 36 名（男性15名，女性21名，平均年齢

$21.3 \pm 0.6$ 歳）とした。車椅子に着座した被検者は 8 の字型の測定コースを上肢駆動，最

大の努力で走行し，測定コースの走行に要した時間が測定された。測定值の絶対信頼性は

Bland-Altman 分析，相対信頼性は級内相関倸数（2.1）を用いて検討した。

[結果］測定值の系統誤差として比例誤差を認めたが加算誤差は認めなかった。測定値の 級内相関係数（2.1）は0.999, 95\%信頼区間は0.999-1.000であった。

[結語] 本研究で開発された車椅子駆動速度の測定・評価法は測定值が内包する誤差の特 性が確認され，また高い検者間信頼性を示した。
\end{abstract}

キーワード：車椅子シーティング, 車椅子駆動能力, 測定・評価法

Abstract: [Purpose] To examine the absolute reliability and relative reliability of a method for measuring and evaluating the wheelchair propulsion skills of turning, accelerating, and decelerating manual wheelchairs among healthy adults.

[Method] Two occupational therapists performed the tests on 36 healthy adults (men: 15; women: 21 ; mean age: $21.3 \pm 0.6$ years). In the figure-of- 8 type of measured course, each participant propelled a wheelchair with arm propulsion and maximum effort. Examiners measured the time required for participants to propel the established course using a stopwatch. The absolute reliability of the measurement value was examined using the BlandAltman analysis, and the relative reliability was examined using the intraclass correlation coefficient (2.1).

[Results] A proportional bias was found as a systematic bias of the measured value; however, no fixed bias was observed. The intraclass correlation coefficient (2.1) of the measured values was 0.999 , with $95 \%$ confidence interval of $0.999-1.000$.

[Conclusion] The measurement and evaluation method developed in this study confirmed the error characteristics in the measured values and showed a high inter-tester reliability.

Key words: wheelchair seating, wheelchair propulsion ability, measurement and evaluation method

\footnotetext{
受付日：2020年 8 月 7 日，採択日：2020年10月 8 日

1) 東京家政大学 健康科学部リハビリテーション学科：テ350-1398 埼玉県狭山市稲荷山 2 - 15 - 1

Department of Rehabilitation, Faculty of Health Sciences, Tokyo Kasei University

電話番号：04-2955-6076 E-mai：kamegaya-t@tokyo-kasei.ac.jp

2-15-1 Inariyama, Sayama, Saitama,350-1398 Japan

Tel:+81(0)429556076 E-Mail: kamegaya-t@tokyo-kasei.ac.jp

2) 福島県立医科大学 新医療系学部設置準備室

Preparing Section for New Faculty of Medical Science, Fukushima Medical University

3) 東北福祉大学 健康科学部リハビリテーション学科

Department of Rehabilitation, Faculty of Health Sciences, Tohoku Fukushi University
} 


\section{I 、はじめに}

人口の急速な高齢化や生活習慣病の増加に伴って車 椅子利用者の数は急伸している ${ }^{1)}$ 。根拠に基づいた医 療 (evidence based medicine) が求められる今日, 車 椅子シーティング（以下，シーティング）もその実践 の効果を科学的根拠に基づて検証することが必要と されている2)。車椅子利用者にとって車椅子は日常生 活における移動手段であり，また必要不可欠な生活用 具でもある。生活用具としての車椅子に求められる役 割は多岐に渡るが, 中でも車椅子の走行性を左右する 車椅子駆動能力の評価はシーティングにおいて重要な 位置を占めている。車椅子に関連するスキルのテスト

(Wheelchair skills tests) に関するシステマティッ ク・レビュー ${ }^{3)}$ によば，シーティングの研究におい て車椅子駆動能力は最も多く採用された効果指標であ り，そのいくつかは車椅子の駆動速度（以下，車椅子 駆動速度）に焦点を当てている ${ }^{4-6)}$ 。

車椅子利用者は日常生活において, 直線的に車椅子 を駆動することに加え, 方向転換や加速 ·減速といっ た駆動のスキルが求められる。車椅子駆動能力の評価 法を開発した先行研究7,8)では, 車椅子駆動速度は直線 路の測定区間で測定されてきた。しかし方向転換や加 速・減速といった駆動のスキルを評価するためには, 直線的なコースに加え, 障害物の回避やカーブ路に 沿った駆動を求めるコースが設定される必要がある。 いくつかの先行研究では 4 本のポールを $3 \mathrm{~m}$ 間隔9), 3 本のポールを $2 \mathrm{~m}$ および $3 \mathrm{~m}$ 間隔 ${ }^{10)}$ で並べたコース をスラローム走行する課題, またスタート地点から 2.5 $\mathrm{m}^{11,12)}$ あるいは $5 \mathrm{~m}^{8}$ の離れた地点に置かれたコーンを 回ってスタート地点まで戻る課題が設定されている。 学会報告では $4 \mathrm{~m}$ 間隔で設置された 2 つ目標物を 8 の字を描くように周る課題が紹介されている ${ }^{13-15)}$ 。 いずれの研究においても特徵的なコースが設定されて いるが，各々のコースが設定された目的や根拠につい て十分な説明はみられず，また測定・評価法の信頼性 も検証されていない。そこで筆者らは，車椅子の方向 転換や加速 ·減速といった駆動のスキルの評価に用い る信頼性を備えた評価法を開発することが必要と考え た。本研究はその予備的検討として, 先行研究の知見 を基に障害物の回避やカーブ路に沿った駆動を求める 測定コースを考案し，そのコースを用いて車椅子駆動 速度を測定する手法の信頼性を，健常成人を対象に検 証した。

\section{II. 対象と方法}

\section{1. 対 象}

検者は作業療法士 2 名（臨床経験20年, 12年), 被 検者は本研究への協力に同意が得られた健常成人 36 名

（男性15名，女性21名，平均年齢21.3 $3 \pm 0.6$ 歳，座位 下腿長 $40.2 \pm 2.2 \mathrm{~cm}$ ) とした。シーティングの対象と される高齢者, 障害者は障害の程度によって測定時の 姿勢や遂行できる課題に差が生じることが予測された。 そのため本研究の被検者は, 検者の指示を十分に理解 し，課題を安全かつ確実に遂行することができる若年 健常成人とした。本研究の内容は東京家政大学健康科 学部研究倫理委員会の審査を受け承認された（審査番 号 SKE2020-05)

\section{2. 方 法}

1 ) 測定方法

測定に用いた車椅子はアルミ製スタンダード車いす 自走型 AR-101（松永製作所社製），車椅子クッショ ンは 5 TC-045（タカノハートワークス社製）であっ た。車椅子のフットサポート・シート間距離は，車椅 子クッションを設置した状態で各被検者の座位下腿長 に適合させた。

本研究では, カーブ路を含む測定区間で被検者の車 椅子駆動能力を評価するため, Figure-of- 8 Walk Test ${ }^{16)}$ を参考に図 1 に示す測定コースを考案した。カーブ路 における歩行能力を評価する Figure-of-8 Walk Test ${ }^{16)}$ では，2 本のコーンが5フィート (約 $1.5 \mathrm{~m})$ の間隔 を置いて設置されていたが，車椅子駆動能力を評価し た先行研究8-15) ではコーン, スタートライン等の複数 の目標物が $2 \mathrm{~m}$ から $5 \mathrm{~m}$ の間隔をおいて設置されて いた。本研究では先行研究を参考として，また日常生 活で求められる車椅子の加速 ·減速も併せて評価する ためには目標物の間に $5 \mathrm{~m}$ 程度の間隔が必要と考え, 2 本のコーンは $5 \mathrm{~m}$ の間隔をおいて設置した。測定 は平坦な床面を有する屋内の一室で行われた。 2 本の コーンを結んだ直線の中間地点に，19mm 幅で白色の ビニールテープを用いて同直線と直交する白線を引き， 測定区間の開始・終了地点（以下，走行開始・終了地 点）とした（図 1)。被検者は車椅子に着座した後, 殿部を車椅子のシート奥へ詰めて座り，股関節・膝関 節 $90^{\circ}$ 屈曲位，足関節底背屈 $0^{\circ}$ を目安に上体を直立さ せた姿勢をとった。続いて被検者は左右の手で車椅子 のハンドリムを把持し，車椅子の両側のキャスターを 走行開始・終了地点の線上に位置させ，走行開始の指 
示が出されるまで静止した状態で待機した。被検者が 車椅子を駆動する方法は上肢駆動とし, 駆動中は背部 をバックサポートから離さないよう求めた。被検者に は「走行始め」の合図とともに車椅子をできる限り速 く駆動し，2 本のコーンに接触することがないよう注 意しながら両コーンを 8 の字を描くように回り, 再び 走行開始・終了地点まで戻るよう指示した。測定区間 を走り終えて再び走行開始・終了地点を通過する際は， 車椅子を減速させることなく，それまでの速度を保ち ながら駆動するよう指示した。2 名の検者は走行開 始・終了地点を挟んで並び立ち, 車椅子のキャスター が走行開始地点を離れてから再び走行開始・終了地点 を通過するまでの所要時間（以下，駆動時間）をデジ タルストップウォッチで測定した。走行開始・終了地 点まで戻った車椅子が白線に対して斜め方向へ走行し ながら通過した場合, 一側のキャスターが白線を通過 したタイミングで測定を終了した。測定の精度は 0.1 秒とし，0.1秒未満の数值は四捨五入した。駆動時間 を車椅子駆動速度の指標とし, 時間が短いほど車椅子 駆動速度が速いものと解釈した。本研究では本法を車 椅子 8 の字駆動テストと称した。

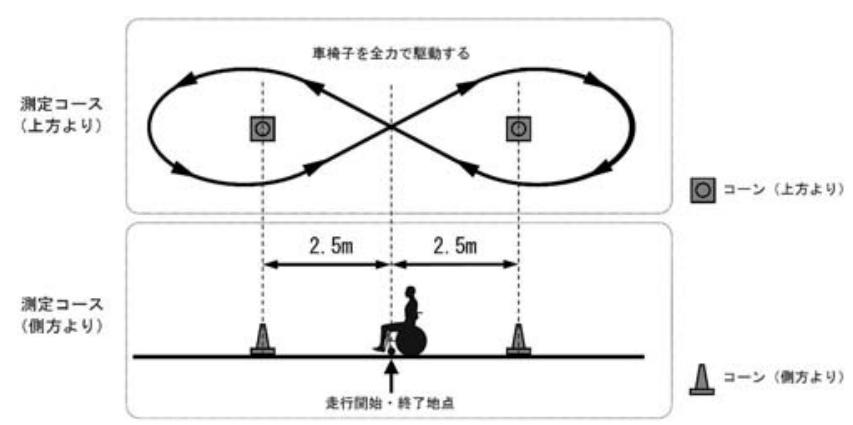

図 1 車椅子 8 の字駆動テストの測定コース

2 本のコーンを $5 \mathrm{~m}$ の間隔を扔いて設置し, それらの中間地点を 測定区間の開始・終了地点（以下, 走行開始・終了地点）とした。 被検者は車椅子に着座し, 車椅子のキャスターを走行開始・終了地 点の白線上に位置させた。被検者は走行開始の合図とともに, 上肢 駆動, 最大の努力で車椅子を駆動し，2 本のコーンの周りを 8 の字 を描きながら 1 周した。検者は車椅子のキャスターが走行開始・終 了地点を離れてから再び走行開始・終了地点を通過するまでの所要 時間をデジタルストップウォッチで測定した。

\section{2 ) 統計解析}

従来,リハビリテーション領域における測定・評価 法の開発研究では級内相関係数などを用いて相対信頼 性を検討した報告が多く見られる ${ }^{17)}$ 。しかし，相対信 頼性を検討するのみでは測定值が内包する誤差, 中で も測定值の真の值から構造的・系統的乘離をもたらす 系統誤差の有無や程度を明らかにすることはできず, 今日の測定・評価法開発では Bland-Altman 分析を用
いて絶対信頼性を検討することが推奨されている ${ }^{17)}$ 。 本研究では測定值の相対信頼性の検討には級内相関係 数 (Interclass Correlation Coefficient: 以下, ICC) を用い，2名の検者によって測定された值から検者間 信頼性の指標となる ICC $(2,1)$ とその $95 \%$ 信頼区間 を算出した。測定值の絶対信頼性は, Bland-Altman 分析を用いて測定時に 2 名の検者から得られた測定值 に扔ける誤差の有無，種類および範囲を検討した。系 統誤差（加算誤差，比例誤差）については，まず 2 名 の検者から得られた $2 つ の$ 測定值の差 (difference, 以下 $d)$ を $y$ 軸, 2 つの測定值の平均值を $x$ 軸にプ ロットしたBland-Altman plotを作成し，散布図の分 布様態を確認した。続いて $2 つ の$ 測定值の差 $(d)$ の $95 \%$ 信頼区間を以下の式 ${ }^{17)}$ より算出し，その範囲が 0 を含まない場合は加算誤差が存在すると判断した。以 下の式では， 2 つの測定值の差の平均は $\bar{d} ， 2$ つの測 定值の差の標準偏差は $S D_{d}$, 標本数は $n$, 自由度 $n-$ 1 の $t$ 值は $t$ と示されている。

$$
\bar{d} \text { の5\%信頼区間 : } \bar{d} \pm t \times \sqrt{\frac{S D_{d}}{n}}
$$

比例誤差の有無は Bland-Altman plotにプロットさ れた 2 変数，すなわち 2 つの測定值の差 $(d)$ と $2 つ$ の測定值の平均值のデータ群について回帰分析を行い, 回帰の有意性を検定するとともに回帰直線の傾きを求 めた。回帰が有意と判断された場合は比例誤差が存在 すると判定した。

測定值はShapiro-Wilk 検定を用いて分布の正規性 を確認した。

統計解析には IBM SPSS Statistics version 26 for windows（日本 IBM 社製）を用い，有意水準は $5 \%$ （p 值 $<0.05 ）$ とした。

\section{III. 結 果}

2 名の検者から得られた測定值は，一方の検者にお いては $16.8 \pm 3.4$ 秒，他方の検者においては $16.8 \pm 3.5$ 秒であった。Shapiro-Wilk 検定によって求められた有 意確率は一方の検者において 0.31 ，他方の検者におい て0.24であり，両検者の測定值は正規分布することが 確認された。

2 名の検者から得られた測定值の検者間信頼性の指 標である ICC（2.1）は0.999，95\%信頼区間は0.999 - 1. 000 であった。

2 名の検者から得られた測定值をもとに作成された Bland-Altman plotを図2に示す。2つの測定值の差 


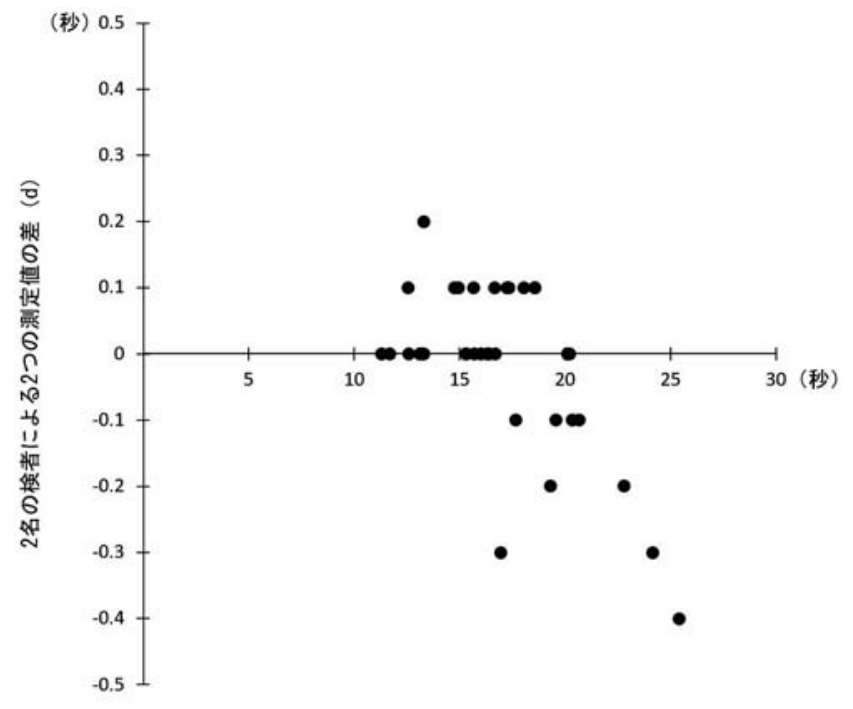

2名の検者による2つの測定値の平均

図 2 測定值の Bland-Altman plot

の $95 \%$ 信頼区間は下限值 - 0.06, 上限值0.03であり, 加算誤差は認められなかった。Bland-Altman plotの 回帰分析の結果より, 回帰直線の有意性は $\mathrm{p}<0.001$, 回帰直線の傾きはー0.02と算出された。

\section{IV. 考 察}

本研究では, 車椅子の方向転換や加速・減速といっ た駆動のスキルの評価に用いる信頼性を備えた測定 · 評価法を開発するため, その予備的検討として車椅子 8 の字駆動テストを考案し, 健常成人を対象としてそ の信頼性を検証した。

Bland-Altman 分析を用いて車椅子 8 の字駆動テス トの測定值の絶対信頼性を検討した結果， 2 つの測定 值の差の $95 \%$ 信頼区間は下限值 - 0.06, 上限值0.03で あり，上限值と下限值との間に 0 が含まれることから 加算誤差は存在しないものと判断した。Bland-Altman plotについて回帰分析を行った結果, 回帰式に有意性

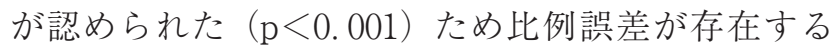
ものと判断した。加算誤差は真の值の大小にかかわら ず正・負の特定方向に生じる誤差，比例誤差は真の值

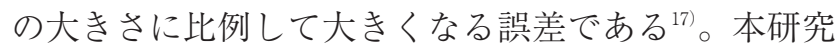
の結果より, 車椅子 8 の字駆動テストの測定值には 正・負の特定方向へ偏って生じる誤差が生じない一方， 測定值が大きくなるに従って測定誤差が大きくなるこ とが示唆された。検者間信頼性の指標である ICC

（2.1）を用いて測定・評価法の相対信頼性を検討し た結果, $\operatorname{ICC}(2.1)$ の值は0.999，95\%信頼区間は0.999 -1.000と示された。ICC は0.7以上であれば信頼性が
高いと判定される ことから, 車椅子 8 の字駆動テス 卜は高い検者間信頼性を備えた評価法と考えられた。

本研究で開発された車椅子 8 の字駆動テストの特徵 は，車椅子駆動の方向を転換するスキルを評価するた めに8の字の測定コースを採用した点, 車椅子の加 速・減速させるスキルを評価するために 2 本のコーン を $5 \mathrm{~m}$ の間隔をおいて設置した点，また被検者へ最 大の努力による駆動を求めた点である。本テストの測 定值の妥当性は今後, 被検者の心身機能や日常生活活 動能力などシーティングで評価される他の事項との関 連を検証することによって明らかにされていく必要が ある。本研究で開発された測定・評価法は検者内信頼 性が検証されておらず，同一の検者が同一の被検者へ 繰り返し測定を行った場合における測定值の一致度は 明らかではない。今後は本測定・評価法の検者内信頼 性が検証される必要がある。本研究は健常成人を対象 に実施されたことから，今後は日常的に車椅子を使用 している高齢者, 障害者を対象に, 測定条件の慎重な 統制と安全に対する配慮のもとで測定・評価法の信頼 性を検証する必要がある。

\section{V. 結 語}

本研究で開発された車椅子 8 の字駆動テストは, 測 定值が内包する誤差の特性が確認され，また高い検者 間信頼性を示したことから，測定上の誤差を考慮する ことによって今後の臨床実践や研究へ応用することが 可能と考えられた。今後の課題は，本テストの測定值 と車椅子利用者の心身機能や日常生活活動能力などと の関連を検証すること，日常的に車椅子を使用してい る高齢者，障害者を対象に本テストの信頼性を検証す ることである。

\section{引用文献}

1)田中マキ子：ポジショニング学 一体位管理の基礎と実践. 中山書店, 東京, 2013, 29.

2) 日本シーティング・コンサルタント協会：車椅子シーティ ング実践ガイドライン2019. https://seating-consultants. org/wp-content/uploads/2019/12/wcseaating2019_12_26. pdf $(2020 / 8 / 7$ 引用 $)$

3) Kilkens O, Post M, Dallmeije A, Seelen H, et al. Wheelchair skills tests: a systematic review. Clin Rehabil, 2003, 17(4): 418 -430 .

4) Agre J, Findley T, McNally M, et al.: Physical Activity Capacity in Children with Myelomeningocele. Arch Phys Med Rehabil, 1987, 68(6): 372-377.

5) Findley T, Agre J: Ambulation in the Adolescent with Spina 
Bifida. II. Oxygen Cost of Mobility. Arch Phys Med Rehabil, 1988, 69(10): 855-861.

6) Simmons S, Schnelle J, MacRae P, et al:: Wheelchairs as Mobility Restraints: Predictors of Wheelchair Activity in Nonambulatory Nursing Home Residents. J Am Geriatr Soc, 1995, 43(4): 384-388.

7) Askari S, Kirby R, Parker K, et al.: Wheelchair Propulsion Test: Development and Measurement Properties of a New Test for Manual Wheelchair Users. Arch Phys Med Rehabil. 2013, 94(9): 1690-1698.

8) 森田智之, 浅沼満, 廣瀬秀行 - 他 : 車椅子駆動能力評価方 法の信頼性と日常生活活動自立度との関連の検討. リハビ リテーション・エンジニアリング, 2014，29(4)：219-225.

9)牧野健一郎, 吉本奈美, 和田太 - 他: 脳卒中片麻痺患者に おける下肢駆動型車椅子の有用性. リハビリテーション医 学, 2003, 40(9): 617-620.

10)坂野裕洋, 植松光俊, 江西一成・他：高齢障害者における 操作機種別電動車いす操作特性の検討. 愛知県理学療法学 会誌, 2007, 19(3) : 119-123.

11) 浅井結, 木村美穂, 渡辺和恵 - 他 : 体幹回旋運動のマシー ントレーニングが車椅子駆動能力に及ぼす影響 一介護老 人保健施設に入所中の車椅子自走者を対象に一. 理学療法 科学, 2006, 21(3) : 281-285.

12) 木村美穂, 浅井結, 渡辺和恵 - 他 : 体幹回旋運動のマシー ントレーニングが車椅子駆動能力に及ぼす影響 一片手片 足駆動者と両手駆動者との比較一. 理学療法科学, 2007, 22 (2) : 239-243.

13)市来詩織, 新井由美子, 網本和: 要介護高齢者における車 椅子操作能力の評価とリハビリテーションに関する検討. 理学療法学, 2007, 34 (suppl-2.2) : 647.

14)和田圭亮, 齋藤隆哉, 網本和：8字車椅子駆動テスト（又 ラロームテスト）に扔ける体幹回旋と視野狭窄が与える影 響. 理学療法学, 2007, 34 (suppl-2.2) : 648.

15)大田原遥, 伊藤貴史, 石井健史 - 他 : 脳卒中片麻痺患者に 対する座面角度調整が車いす駆動スキルに与える影響 〜 スラロームテスト・ 三次元動作解析装置を用いた比較検討 〜。車椅子シーティング研究, 2019, 4 : 99.

16) Hess R, Brach J, Piva S, et al. : Walking Skill Can Be Assessed in Older Adults: Validity of the Figure-of-8 Walk Test. Phys Ther, 2010, 90(1): 89-99.

17)下井俊典: 評価の絶対信頼性. 理学療法科学, 2011, 26 (3) : 451-461.

18) 対馬栄輝：SPSS で学ぶ医療系デー夕解析. 東京図書, 東 京, 2007, 212. 